\title{
Exploring the Differential Effects of Service-Learning on Students' Sense of Belonging: Does Social Class Matter?
}

Krista M. Soria

University of Minnesota

Ashley S. Hufnagle

University of Minnesota

Isabel Lopez-Hurtado

University of Minnesota

Tai Do

University of Minnesota

\section{Recommended Citation:}

Soria, K. M., Hufnagle, A. S., Lopez-Hurtado, I., \& Do, T. (2019). Exploring the differential effects of service-learning on students' sense of belonging: Does social class matter? International Journal of Research on Service-Learning and Community Engagement, 7(1), Article 8. 


\title{
Exploring the Differential Effects of Service-Learning on Students' Sense of Belonging: Does Social Class Matter?
}

\author{
Krista M. Soria \\ Ashley S. Hufnagle \\ Isabel Lopez-Hurtado \\ Tai Do \\ University of Minnesota
}

\begin{abstract}
The purpose of the study discussed in this article was to investigate the differential effects of servicelearning experiences on students' sense of belonging based on students' social-class background. We utilized Student Experience in the Research University (SERU) survey data from eight large public research universities and propensity score matching to construct matched pairs of students who did (and did not) complete service-learning. The results suggest that service-learning courses had significant positive effects on lower/working-class students' sense of belonging but no effects on middle-/upper-class students' sense of belonging.
\end{abstract}

Keywords: college students, research universities, sense of belonging, SERU survey, service-learning, social class

Disparities in student enrollment in higher education remain high among students from different socioeconomic or social-class backgrounds. While more students from lower socioeconomic households have enrolled in two- and four-year colleges over the last decade (from $50.9 \%$ in 2006 to $65.4 \%$ in 2016), students from higher income backgrounds are still significantly more likely than lower income students to enroll in higher education (82.5\% in 2016; National Center for Education Statistics [NCES], 2017). Despite the encouraging gains in enrollment, students from lower socioeconomic and social-class backgrounds also lag behind their middle- and upper-income peers in degree attainment: $60 \%$ of students from high socioeconomic status backgrounds earned a bachelor's degree or higher within eight years of enrollment compared to just $14 \%$ of students from low socioeconomic backgrounds (NCES, 2015). The persistent disparities in higher education enrollment and attainment among students from different social-class backgrounds is troubling, especially given the many benefits associated with earning a baccalaureate degree. For instance, higher education opens pathways to greater employment opportunities: Scholars predict that postsecondary education may be required for up to $65 \%$ of jobs by 2020 (Carnevale, Smith, \& Strohl, 2013). Considering the educational attainment gap between students from lower and upper social-class backgrounds, there is clearly more work that higher education institutions need to undertake to increase degree completion rates among students from lower class and working-class families.

Several researchers have explored the roots of socioeconomic disparities in college attendance and completion rates. While factors such as affordability and financial aid certainly influence students' decisions to attend, persist in, and graduate from college (Paulsen \& St. John, 2002; Singell, 2004; Wessel, Bell, McPherson, Costello, \& Jones, 2006), scholars have also cited the importance of psychosocial factors, such as sense of belonging, in students' decisions to persist and graduate (Hausmann, Schofield, \& Woods, 2007; Strayhorn, 2012). Baumeister and Leary (1995) posited that a sense of belonging is a fundamental human motivation defined by stable and positive interpersonal relationships. When applied to an educational context, students' sense of belonging measures the extent to which students feel psychologically connected to or socially integrated in 
their college or university community (Hausmann et al., 2007; Hurtado \& Carter, 1997; Hurtado \& Guillermo-Wann, 2013). In particular, scholars have surmised that students from lower socioeconomic and social-class backgrounds have a lower sense of belonging because they perceive that they do not belong in the middle- and upper-class culture of higher education and therefore leave before completing their degrees (Hurst, 2010, 2012; Soria, 2015b).

Institutions can take steps to increase a sense of belonging among students from lower socialclass backgrounds. Lower income and working-class students tend to live off campus, spend less time on campus, work more hours, and are less involved in social activities due to their expense (Rubin, 2011; Soria, 2015b); therefore, curricular experiences may represent more powerful opportunities to increase students' sense of belonging than co-curricular experiences because academic service-learning courses can be embedded into courses required for completion of a major or graduation and may not impose upon students' non-academic time, which may be spent taking care of families or in employment. In particular, curricular service-learning - courses that include community service and volunteerism components - could serve as an important active-learning pedagogy to increase students' social integration and subsequent retention (York \& Fernandez, 2018). Yet, to date, very few researchers have explored the connections between service-learning courses and students' sense of belonging, namely whether service-learning has differential impacts on outcomes based upon students' social-class background. Therefore, the purpose of this article is to explore the differential effects of service-learning courses on students' sense of belonging, conditional upon students' social class.

\section{Service-Learning and Sense of Belonging}

Over the last two decades, scholarship documenting the benefits of service-learning courses has burgeoned in the field of higher education. Participation in service-learning courses has been positively associated with significant gains in academic outcomes (Astin \& Sax, 1998; Furco, JonesWhite, Huesman, \& Gorny, 2016; York, 2016), social and affective outcomes (Eyler \& Giles, 1999; Furco et al., 2016; Weiler et al., 2013; Wilson, 2011; York, 2016), citizenship self-efficacy (Iverson \& James, 2013), and students' overall sense of political and civic responsibility (Astin, Vogelgesang, Ikeda, \& Yee, 2000; Weiler et al., 2013). However, amid the extant research on service-learning, very few authors have explored the potential for service-learning courses to positively impact undergraduates' sense of belonging. In fact, according to York and Fernandez (2018), "scholars have largely ignored the effects of service-learning participation on students' sense of belonging" (p. 580). The few scholars who have explored the effects of service-learning on students' sense of belonging have discovered positive effects; however, their studies were limited by small sample sizes (e.g., 16 Hispanic students; Pak, 2018) or limited sample groups (e.g., transfer students; York \& Fernandez, 2018).

To conceptualize connections between service-learning and sense of belonging, one can draw upon research on the benefits of community service, which is an embedded component of servicelearning courses. Scholars have generally found positive relationships between participation in community service and students' sense of belonging, although, like research on service-learning, there are few published studies documenting such relationships. After analyzing a national sample of undergraduates, Soria, Troisi, and Stebleton (2012) discovered that students who participated in community service had a significantly greater sense of belonging compared to their peers who did not participate. Nuñez (2009) analyzed a smaller sample of Latinx college students and discovered that community-service participation had direct positive effects on students' sense of belonging as well as indirect positive effects on sense of belonging through positive cross-racial interactions, negative campus climates, and an obligation to give back to communities.

In general, service-learning has been theorized to benefit students' sense of belonging and social integration because of strong connections between in-class and out-of-class experiences, opportunities for students to connect their personal experiences with academic curricula, and 
beneficial intersections between academic and social integration (Reason, 2009; York \& Fernandez, 2018). Students can also create a community on campus by establishing relationships with faculty, staff, peers, and community members through their service-learning experiences (Johnson et al., 2007; Nora, Kramer, \& Itzen, 1996; Velásquez, 1999; Yeh, 2010). Furthermore, community service and service-learning have the potential to be culturally relevant and engaging because they can provide opportunities for students to positively transform their communities, validate students' cultural backgrounds and identities, connect students to peers from diverse backgrounds, and involve students in discussions and activities related to solving real social dilemmas (Museus, Yi, \& Saelua, 2017). Culturally engaging campus environments can support students' sense of belonging; however, service opportunities that view students' communities of origin under a deficit lens may alienate students from a campus instead of enhancing their connections to it (Museus et al., 2017).

While the aforementioned authors have highlighted the extended benefits of participation in service-learning, very few scholars have examined whether participation in service-learning courses is associated with students' sense of belonging, even though this relationship has been hypothesized (Carver, 1997). Furthermore, no researchers have examined the differential effects of servicelearning on student outcomes based on demographic factors, such as social class, although researchers have long demonstrated that students from different backgrounds experience-and benefit from - campus activities in unique ways (Brownell \& Swaner, 2009; Johnson et al., 2007; Johnson, Dugan, \& Soria, 2017). Given the persistent disparities in students' sense of belonging in the context of their social class (Ostrove \& Long, 2007; Soria, 2015b; Soria \& Bultmann, 2014), it is time to examine whether service-learning has differential impacts on students' belonging based on their social class. Therefore, the primary research question guiding this study was as follows: Does enrollment in service-learning courses have a differential effect on students' sense of belonging conditional upon students' social class?

\section{Conceptual Framework}

We employed Astin's (1993) input-environment-output theory in our analyses. Astin hypothesized that the background characteristics of college students (inputs) and relevant aspects of the college experience (environment) influence student outcomes. We integrated Astin's model in our statistical approach by considering the role of students' pre-college characteristics ("input" variables such as demographics) and additional collegiate experiences ("environment" variables, including students' residence on campus) in their sense of belonging. As background to this article, we also employed Bourdieu and Passeron's (1977) theory of social reproduction, which suggests that educational systems reproduce social classes by granting continued advantages to children of culturally (and economically) wealthy backgrounds who can successfully navigate educational systems. Bourdieu and Passeron's theory suggests that students from lower social-class backgrounds may feel as though they do not belong in middle-/upper-classed higher education institutions due to the social-class cultural mismatch. Higher education institutions are designed to support and legitimize those from middle/upper classes while shutting out those from low-income/working classes (Soria, 2015b). In our study, we sought to explore whether one practice - service-learning - has the potential to disrupt those greater social systems preventing low-income/working-class students from feeling legitimized in the academy.

\section{Methodology}

\section{Instrument}

We utilized data from the Student Experience in the Research University (SERU) survey, which was administered to eight large public research universities in spring 2017. The SERU survey contains over 600 items; its purpose is to gather data on students' experiences in higher education, including 
their academic engagement, sense of belonging, and participation in community engagement, among other areas (Douglass, Thomson, \& Zhao, 2012; Soria \& Thomas-Card, 2014). Previous researchers have provided evidence for the internal consistency of students' responses over several administrations of the survey (Chatman, 2011; Douglass et al., 2012). Response rates ranged between $15 \%$ and $30 \%$ at the participating institutions $(n=54,778)$.

\section{Participants}

We reduced the sample of participants after utilizing propensity score matching procedures (described in a later section) to match students who enrolled in a service-learning or communitybased learning experience $(n=9,621)$ with students who did not have those service-learning or community-based learning experiences $(n=9,621)$. Table 1 summarizes the demographic information from the sample. In the survey, students identified their social class in one of five categories: low-income or poor, working-class, middle-class, upper-/professional- middle-class, or wealthy. Researchers have provided evidence for the validity of students' self-reported social class in the SERU survey (Soria \& Barratt, 2012).

Table 1. Demographic Information for Sample

\begin{tabular}{|c|c|c|}
\hline Self-Reported Characteristic & $n$ & $\%$ \\
\hline Male/Man & 5821 & 30.3 \\
\hline Female/Woman & 13036 & 67.7 \\
\hline Trans Male/Trans Man & 25 & 0.1 \\
\hline Trans Female/Trans Woman & 25 & 0.1 \\
\hline Genderqueer/Gender Non-Conforming & 131 & 0.7 \\
\hline Prefer to self-describe gender & 105 & 0.5 \\
\hline Decline to state gender & 99 & 0.5 \\
\hline American Indian & 40 & 0.2 \\
\hline African American & 962 & 5.0 \\
\hline Hispanic & 2371 & 12.3 \\
\hline Asian & 2946 & 15.3 \\
\hline White & 11154 & 57.9 \\
\hline Native Hawaiian or Pacific Islander & 56 & 0.3 \\
\hline Declined to state race/ethnicity & 316 & 1.6 \\
\hline International & 664 & 3.5 \\
\hline Multiracial & 745 & 3.9 \\
\hline Low-income or poor & 1430 & 7.4 \\
\hline Working-class & 3484 & 18.1 \\
\hline Middle-class & 7366 & 38.3 \\
\hline Upper-middle- or professional-middle-class & 6326 & 32.9 \\
\hline Wealthy & 636 & 3.3 \\
\hline Neither parent/guardian attended any college & 2326 & 12.1 \\
\hline $\begin{array}{l}\text { One or both parents/guardians attended some } \\
\text { college, but neither has a four-year degree }\end{array}$ & 2674 & 13.9 \\
\hline One parent/guardian has a four-year degree & 3133 & 16.3 \\
\hline Both parents/guardians have a four-year degree & 4553 & 23.7 \\
\hline $\begin{array}{l}\text { One parent/guardian has a graduate or professional } \\
\text { degree }\end{array}$ & 3516 & 18.3 \\
\hline
\end{tabular}




\begin{tabular}{lcc}
\hline Self-Reported Characteristic & $\boldsymbol{n}$ & $\mathbf{\%}$ \\
\hline $\begin{array}{l}\text { Both parents/guardians have a graduate or } \\
\text { professional degree }\end{array}$ & 3040 & 15.8 \\
& & \\
$\begin{array}{l}\text { Non-Pell grant recipient } \\
\text { Pell grant recipient }\end{array}$ & 13301 & 69.1 \\
\hline
\end{tabular}

\section{Measures}

Covariate variables. We selected several measures as covariates in propensity score matching that have been theoretically or empirically related to either the outcome or the treatment (Stuart, 2010). Few researchers have analyzed predictors of students' participation in service-learning courses, so we utilized predictors of participation in community service as we selected covariates. We considered students' self-reported gender, age, race/ethnicity, and political orientation (Astin \& Sax, 1998; Cruce \& Moore, 2007; Lester, Brown Leonard, \& Mathias, 2013; Mitchell, Schneider, \& Soria, 2017; Nuñez, 2009). Students indicated their political orientation on a scale from $1=$ very liberal to $8=$ very conservative. We also included measures of socioeconomic status, such as social class, receipt of a Pell grant, and parental education (Cruce \& Moore, 2007; Marks \& Jones, 2004). Students provided the highest level of their parents' education on a scale from $1=$ neither parent/guardian attended college to $6=$ both parents have a graduate degree (with various combinations of attending or completing four-year or graduate degrees in between). Finally, we also included whether students lived on campus $(0=n o, 1=y e s)$, whether they participated in a leadership program $(0=n o, 1=y e s)$, how frequently they participated in student clubs or organizations (measured on a scale from $1=0$ hours per week to $8=$ more than 30 hours per week), their academic level (e.g., freshman, sophomore), how many hours per week they were employed off campus, and their academic majors (Astin \& Sax, 1998; Marks \& Jones, 2004; Serow \& Dreyden, 1990). We dummy-coded academic majors into nine categories, with undeclared majors serving as a common referent: agriculture, STEM, humanities, business, health and human services, education, design, natural sciences, and social sciences.

Independent variable. In the SERU survey, students responded to an item in which they indicated whether they had previously completed or were currently enrolled in a service-learning or community-based learning experience $(0=n o, 1=y e s)$. Of the original sample $(n=54,778), 27.7 \%$ of students indicated they had already completed or were currently enrolled in service-learning.

In our analyses, we also included several control variables that previous researchers have identified as associated with students' sense of belonging: students' academic engagement, perceptions of campus climate for diversity, academic interactions with classmates, and academic disengagement (Dennis, Phinney, \& Chuateco, 2005; Soria et al., 2012; Soria \& Alkire, 2015; Soria \& Bultmann, 2014; Soria \& Stebleton, 2013; Stebleton, Soria, \& Huesman, 2014).

To measure students' academic engagement, students responded to three items in which they indicated the frequency $(1=$ never to $6=$ very often $)$ with which they had contributed to a class discussion, brought up ideas or concepts from different courses during class discussions, or asked an insightful question in class during the academic year. To measure students' perceptions of campus climate, students indicated their agreement $(1=$ strongly disagree to $6=$ strongly agree $)$ with five items: "students of my race/ethnicity are respected on this campus"; "students of my socioeconomic status are respected on this campus"; "students of my gender are respected on this campus"; "overall, I feel comfortable with the climate for diversity and inclusiveness at this university"; and "the university is a welcoming campus." To measure students' academic disengagement, students indicated the frequency $(1=$ never to $6=$ very often $)$ with which they had turned in a course assignment late, gone to class unprepared, or skipped class. Finally, to measure students' classmate interactions, students indicated the frequency $(1=$ never to $6=$ very often $)$ with which they had 
studied with a group of classmates outside of class, worked on class projects with classmates outside of class, or helped a classmate to better understand the course material when studying together.

Dependent variable. We developed our dependent variable, students' sense of belonging, from four survey items. Students rated their satisfaction with their overall social experience and overall academic experience $(1=$ very dissatisfied to $6=$ very satisfied $)$. Students also rated their agreement $(1$ = strongly disagree to 6 = strongly agree $)$ with two items: "I feel like I belong at this university" and "I feel valued as an individual on this campus."

\section{Data Analyses}

We first utilized propensity score matching techniques in SPSS 23.0 (Thoemmes, 2012) to compute propensity scores (i.e., the estimated probability that students participated in service-learning) for individual students. We used exact matching to match on students' social class and then 1:1 nearest neighbor matching on various covariates so that each student in the treatment condition was matched to a student in the control condition who had the most similar estimated propensity score within each social class (Austin, 2011). We matched without replacement and discarded all units that fell outside the area of common support in order to avoid extrapolation to units that were so dissimilar that no comparisons could be made to other units (Thoemmes, 2012). We imposed a caliper of .20 of the standard deviation of the logit of the propensity score to avoid inadequate matches (Austin, 2011). This process resulted in a matched dataset of comparable treatment and comparison students.

We examined whether the matching procedures balanced the distribution of variables in both the treatment and control groups by first reviewing the standardized mean differences (i.e., the mean differences between the two groups divided by the standard deviation of the control group) in the treatment and control groups before and after matching. We detected no large imbalances above .25 after matching in each analysis, meeting the threshold suggested by Rosenbaum and Rubin (1985). We also examined the overall imbalance test (Hansen \& Bowers, 2008) and found that no variables were significantly unbalanced after matching. Additionally, the total relative imbalance measure developed by Iacus, King, and Porro (2009) was smaller in the matched sample than in the unmatched sample. Our visual inspections of histograms of propensity scores pre- and post-matching suggested that the magnitude of standardized differences was reduced, and histograms of standardized differences of all terms pre- and post-matching suggested that the standardized differences post-matching were centered on zero and that no systematic differences existed after matching (Thoemmes, 2012). Therefore, the covariates within the treatment and control groups differed significantly before matching procedures were implemented, and the propensity score matching decreased bias by making the observed and treatment groups more similar with regard to their covariates.

We then utilized a factor analysis on 18 survey items to reveal latent variables that explained correlations between the variables (or dimensions). Traditional methods of exploratory factor analysis rely upon the Kaiser criterion, the scree test, Bartlett's test, and eigenvalues, all tests that may overestimate or underestimate the true number of factors (Basto \& Pereira, 2012; Costello \& Osborne, 2005). We therefore utilized parallel analysis (Velicer, Eaton, \& Fava, 2000), Velicer's (1976) minimum average partial (MAP) method, and Raiche, Roipel, and Blais's (2006) optimal coordinate (OC) method to estimate the factors (Courtney, 2013). We used the procedures outlined by Courtney (2013) to analyze the data using SPSS R-Menu v.2.0 (Basto \& Pereira, 2012). Velicer's MAP values suggested a distinct fifth-step minimum squared average partial correlation, and parallel analysis suggested that five factors should be retained. Against a plot of eigenvalues, the OC procedures estimated five factors. The measures of sampling adequacy were all over 0.40, suggesting that all variables could be retained in the factors, and the goodness of fit statistics suggested that the factorial model had good fit $(\mathrm{GFI}=.984$, AGFI $=.976$, RMSR $=.07)$. With this evidence, we retained the following factors: academic engagement $(\alpha=.851)$, academic disengagement $(\alpha=.910)$, sense of belonging $(\alpha=.858)$, campus climate $(\alpha=.889)$, and classmate interactions $(\alpha=.878$; see 
Table 2). The internal consistency of the variables in the factors was consistent with prior research (Soria \& Stebleton, 2013; Stebleton et al., 2014). We computed the factor scores using the regression method and standardized the scores with a mean of zero and a standard deviation of one.

Table 2. Factor Loadings

\begin{tabular}{lccccc}
\hline SERU Survey Item & $\begin{array}{c}\text { Campus } \\
\text { Climate }\end{array}$ & $\begin{array}{c}\text { Sense of } \\
\text { Belonging }\end{array}$ & $\begin{array}{c}\text { Academic } \\
\text { Engagement }\end{array}$ & $\begin{array}{c}\text { Classmate } \\
\text { Interaction }\end{array}$ & $\begin{array}{c}\text { Academic } \\
\text { Disengagement }\end{array}$ \\
\hline
\end{tabular}

Students of my 0.855

race/ethnicity are respected

on this campus.

Students of my $\quad 0.816$

socioeconomic status are

respected on this campus.

Students of my gender are $\quad 0.796$

respected on this campus.

Overall, I feel comfortable $\quad 0.713$

with the climate for diversity

and inclusiveness at this

university.

The university is a

welcoming campus.

Overall social experience.

0.863

I feel that I belong at this $\quad 0.850$

university.

Overall academic experience

0.809

I feel valued as an individual

0.788

at this campus.

Contributed to a class

0.910

discussion

Brought up ideas or concepts

0.890

from different courses

during class discussions

Asked an insightful question

in class

Studied with a group of

classmates outside of class

0.888

Helped a classmate better

0.876

understand the course

material when studying

together

Worked on class projects

with classmates outside of

class

Gone to class unprepared 


\begin{tabular}{|c|c|c|c|c|c|}
\hline SERU Survey Item & $\begin{array}{l}\text { Campus } \\
\text { Climate }\end{array}$ & $\begin{array}{c}\text { Sense of } \\
\text { Belonging }\end{array}$ & $\begin{array}{c}\text { Academic } \\
\text { Engagement }\end{array}$ & $\begin{array}{l}\text { Classmate } \\
\text { Interaction }\end{array}$ & $\begin{array}{c}\text { Academic } \\
\text { Disengagement }\end{array}$ \\
\hline Skipped class & & & & & 0.786 \\
\hline $\begin{array}{l}\text { Turned in a course } \\
\text { assignment late }\end{array}$ & & & & & 0.781 \\
\hline
\end{tabular}

Although the data utilized in this study were from multiple institutions - and, thus, the students were "nested" within different contexts - we did not utilize hierarchical linear modeling techniques for analyses for several reasons. We computed the intraclass correlation coefficients (ICCs), an estimate of the proportion of between-institution variance compared to within-institution variance, and discovered that the coefficients were all less than .001, suggesting sufficient independence of observations in the different groups of institutions (Hedges \& Hedberg, 2007).

Finally, we used hierarchical linear regression to examine the associations between participation in service-learning and sense of belonging, controlling for academic engagement, academic disengagement, campus climate, and classmate interactions. We entered the four collegiateexperience variables (i.e., academic engagement, academic disengagement, campus climate, and classmate interactions) into the first block and then entered service-learning into the second block to ascertain the amount of variance in sense of belonging explained by service-learning above and beyond the variance explained by the four variables in the first block. We split the file into the five social-class groups (low-income or poor, working-class, middle-class, upper-/professional-middle class, and wealthy) to examine the differential effects of service-learning on those groups. Given the large sample size, we used more conservative $p$-values $(p<.001)$ in our analyses (Gelman \& Hill, 2007).

\section{Limitations}

This study had several limitations. First, although the sample was derived from a large census survey administered at several institutions, the sample was not randomly selected, and it is difficult to know the extent students at these institutions represented other students enrolled in colleges and universities in the United States. Further, these institutions were research-extensive institutions; thus, the results have limited generalizability to other student populations. Additionally, service-learning participation was self-reported by students and was thus subject to students' own interpretation of the service-learning construct. Students could have had different conceptualizations of service-learning based upon their individual experiences. This study was also limited to the items available in the survey, and we cannot disregard the possible effect of unmeasured variables that may have impacted the relationship between service-learning participation and students' sense of belonging.

Finally, matching methods using propensity scores present a variety of limitations: (1) selection of covariates in the initial logistic regression is highly subjective, and misspecification of the initial logistic model is common (King \& Nielsen, 2016); (2) propensity score matching reduces the sample size of participants for the outcome analysis, introducing potential bias in the final model (Peikes, Moreno, \& Orzol, 2008); and (3) the procedures cannot account for unmeasured covariates that may be related to participation in service. While propensity score matching techniques have been known to be among the most robust methods for reducing bias due to imbalances in observed covariates (Rubin, 1973), these techniques are not meant to reproduce a randomized control trial; therefore, the results should be interpreted with caution. While we implemented propensity score matching to address self-selection bias in service-learning program participation, generalizations derived from self-selection in response to a survey must be interpreted with caution as well. 


\section{Results}

The results from the regression analyses (Table 3 ) suggest that there were positive effects of servicelearning on sense of belonging only among low-income/poor and working-class students $(\beta=.067, p$ $<.001$ and $\beta=.059, p<.001$, respectively). Participation in service-learning courses was not significantly associated with middle-class, upper-/professional-middle-class, or wealthy students' sense of belonging. Additionally, we found that service-learning accounted for a significant amount of variance above and beyond the four control variables (i.e., campus climate, academic engagement, classmate interactions, and academic disengagement) only in the model for low-income/poor students and in the model for working-class students. Among students from all social-class groups, campus climate and classmate interactions were positively associated with sense of belonging. Academic engagement was positively associated with low-income or poor, working-class, middleclass, and upper-/professional-middle class students' sense of belonging. Academic disengagement was only negatively associated with working-class, middle-class, and upper-/professional-middleclass students' sense of belonging.

Table 3. Results from the Sense of Belonging Regression Models

\begin{tabular}{|c|c|c|c|c|c|c|c|c|c|c|}
\hline \multirow[t]{2}{*}{ SERU Factor } & \multicolumn{2}{|c|}{$\begin{array}{l}\text { Low-Income } \\
\text { or Poor }\end{array}$} & \multicolumn{2}{|c|}{$\begin{array}{l}\text { Working- } \\
\text { Class }\end{array}$} & \multicolumn{2}{|c|}{ Middle-Class } & \multicolumn{2}{|c|}{$\begin{array}{c}\text { Upper-/ } \\
\text { Professional- } \\
\text { Middle- } \\
\text { Class }\end{array}$} & \multicolumn{2}{|c|}{ Wealthy } \\
\hline & $\beta$ & $p$ & $\boldsymbol{\beta}$ & $p$ & $\boldsymbol{\beta}$ & $p$ & $\boldsymbol{\beta}$ & $p$ & $\boldsymbol{\beta}$ & $p$ \\
\hline Campus climate & 0.535 & $* * *$ & 0.441 & $* * *$ & 0.418 & $* * *$ & 0.396 & $* * *$ & 0.511 & $* * *$ \\
\hline Academic engagement & 0.144 & $* * *$ & 0.123 & $* * *$ & 0.114 & $* * *$ & 0.136 & $* * *$ & 0.088 & \\
\hline Classmate interactions & 0.106 & $* * *$ & 0.174 & $* * *$ & 0.167 & $* * *$ & 0.178 & $* * *$ & 0.173 & $* * *$ \\
\hline $\begin{array}{l}\text { Academic } \\
\text { disengagement }\end{array}$ & -0.043 & & -.090 & $* * *$ & -0.106 & $* * *$ & -0.104 & $* * *$ & -0.009 & \\
\hline$R^{2}$ & 0.360 & $* * *$ & 0.289 & $* * *$ & 0.264 & $* * *$ & 0.241 & $* * *$ & 0.372 & $* * *$ \\
\hline Service-learning & 0.067 & $* * *$ & 0.059 & $* * *$ & 0.024 & & 0.023 & & 0.041 & \\
\hline$R^{2} \Delta$ & 0.005 & $* * *$ & 0.003 & $* * *$ & 0.000 & & 0.000 & & 0.002 & \\
\hline Final $R^{2}$ & 0.365 & $* * *$ & 0.292 & $* * *$ & 0.264 & $* * *$ & 0.241 & $* * *$ & 0.374 & $* * *$ \\
\hline
\end{tabular}

Note. ${ }^{* * *} p<.001$

\section{Discussion}

To date, researchers have not examined the conditional effects of service-learning on student outcomes based on students' demographic backgrounds. Given this gap, scholars and practitioners have not been able to accurately gauge the effectiveness of service-learning participation among different groups of students. Thus, the primary aim of this research study was to initiate an investigation into whether enrollment in service-learning classes may have unique outcomes for students based on their social-class background. We discovered that there are differential effects of service-learning on students' sense of belonging, based on their social class: students from lowerclass and working-class backgrounds who participated in service-learning had a significantly higher sense of belonging compared to their peers who did not participate in service-learning, while middle- 
/upper-class students who participated in service-learning did not have a significantly different sense of belonging compared to their peers. Given these findings, we argue that additional studies on service-learning participation should be conducted to ascertain whether service-learning is differentially impactful for students based on their demographic characteristics.

The results of this study offer additional key contributions to the field of community engagement in higher education. First, the results offer support for service-learning as a potential pedagogical mechanism for improving students' sense of belonging - especially among students from diverse backgrounds who typically have a lower sense of belonging compared to their peers (Soria, Stebleton, \& Huesman, 2013). Service-learning program participation may foster conducive environments for students to form positive and stable social bonds (Baumeister \& Leary, 1995) among faculty, peers, and community members, which may further facilitate campus-community integration (Hurtado \& Carter, 1997). Second, the results reveal that service-learning may not have democratic outcomes for all students, especially as it relates to students' sense of belonging. As researchers and practitioners continue to illuminate the benefits of service-learning courses, they should also attend to considerations about whether this pedagogical technique works best for all learners.

Awareness of service-learning's differential effects on students' sense of belonging based on their social class is important for scholars and practitioners who seek to disrupt systematic social reproduction (Bourdieu \& Passeron, 1977). In particular, practitioners seeking to elevate lower- and working-class students' sense of belonging in the academy may find that service-learning classes offer opportunities to support students' social integration. Acknowledgement of these class differences can inform specific practice recommendations to more effectively improve students' sense of belonging at their university, which will, ideally, transfer to their perceptions of acceptance within higher education more broadly. Our results lend support to the theorized idea that servicelearning is a high-impact educational practice that could benefit lower/working-class students by boosting their overall sense of belonging through opportunities to establish deeper connections to their peers, faculty, institution, and greater community.

While service-learning participation contributes to students' sense of belonging above and beyond the included covariates, it is important to interpret these findings with caution due to the small effect size and the amount of variance explained by service-learning in the models for lowincome and working-class students. We cannot neglect the contribution of other variables, such as those included in this study, on students' sense of belonging. Instead, we view service-learning as one of many practices that might have a beneficial impact on students from lower class backgrounds when implemented concurrently. Thus, service-learning is not a "silver bullet" that should be required for all lower income students, but is instead one evidence-based practice in a larger constellation of activities and interventions that can facilitate students' sense of belonging. Notably, Kuh (2003) conceptualized student engagement as a two-way street - a dynamic relationship between the time and energy students personally invest in their education and the effort that institutions devote to implementing efficacious educational practices and programming. In essence, the "magic" is found in this recursive relationship when purposeful university programming acts in conjunction with students' motivational factors to elicit and foster students' sense of belonging. With Kuh's conceptualization of student engagement in mind, we have developed practical recommendations for implementing effective service-learning programs for students from lower social-class backgrounds.

In order for students of low-income/working-class backgrounds to most effectively reap the benefits of service-learning, this pedagogical technique must be implemented with high fidelity and tailored to acknowledge the unique characteristics and identities of this group of students. As demonstrated by past research, lower income students often face a unique set of challenges and obstacles, such as balancing competing responsibilities of school and employment (Soria, 2015b). With these considerations in mind, we argue that service-learning should be infused into students' primary curricular programming, or part of their "normal" or "expected" course load, as opposed to 
an "extra" responsibility to take on outside of class. Such an integration ensures that students who have less time or financial resources to participate in co-curricular activities have the potential to receive the boost in sense of belonging that is cultivated during the process of participating in service-learning.

Additionally, active reflection is often cited as a key ingredient for quality service-learning courses. Eyler (2002) suggested that service-learning programs that thoroughly integrate service and academic learning through continuous reflection promote development of the knowledge, skills, and cognitive capacities necessary to deal effectively with real, complex social issues that challenge citizens. Hatcher and Bringle (1997) offered a few key guidelines for effective reflection activities, which, mainly: are linked to learning objectives, are guided by the instructor, occur regularly, allow for feedback and assessment, and include a clarification of values (particularly when students encounter unfamiliar situations that challenge and contradict their perspectives). Students from lower/working-class backgrounds may have first-hand experience with many of the inequalities or societal issues addressed in service-learning classrooms. Constant and structured reflection can therefore provide them with the tools for understanding and critiquing structural inequalities while make meaning of their own personal experiences (Yeh, 2010).

Critical theorists of service-learning programs have also argued that service-learning opportunities that view students' home communities through a deficit lens may actually counter the intended goal by further alienating students rather than enhancing their sense of belonging (Museus et al., 2017). We recognize that this is a real and valid concern. Therefore, in order to address this criticism, we argue that service-learning works best when it is culturally relevant, when students' unique identities and experiences are validated, and when students are able to see their academic service experience as cultivating a skillset that would be useful for solving problems in their communities. Ensuring that service-learning programs operate in this way requires intentionality on the part of key stakeholders and continued institutional investment in order to develop deep, mutually beneficial, and sustainable community partnerships.

In addition to the more immediate boost in sense of belonging from service-learning program participation for students from lower social-class backgrounds, these results offer important theoretical implications for improving longer term academic outcomes. Although outside the scope of the current article, we hypothesize that when service-learning opportunities are structured and implemented in accordance with the aforementioned guidelines, these experiences may create a pathway to a host of positive downstream effects for students. In particular, the substantive literature suggests that students' sense of belonging is a key predictor of students' educational achievement and persistence in higher education (Maestas, Vaquera, \& Muñoz Zehr, 2007; Strayhorn, 2012). Students' sense of belonging also has implications beyond retention and graduation: Scholars have found that students' sense of belonging is positively associated with their academic achievement (Han, Farruggia, \& Moss, 2017; Walton \& Cohen, 2011); adjustment to higher education (Ostrove \& Long, 2007); physical health, mental health, and well-being (Fink, 2014; Hale, Hannum, \& Espelage, 2005; Walton \& Cohen, 2011); and other developmental outcomes, such as leadership (Soria \& Mitchell, 2015), multicultural competence (Soria, 2015a; Soria \& Mitchell, 2015), and criticalthinking skills (Soria, 2015b). Critically, this lends theoretical support for service-learning's longterm implications for educational attainment and development, which, on a broader scale, has the potential to contribute to a more (economically) equitable society.

\section{Conclusion}

In summary, despite promising gains in university enrollment, persistence rates and degree attainment still remain far lower for students from lower social-class backgrounds as compared to their high-income peers. Results from this study suggest that there are positive effects of servicelearning on lower/working-class students' sense of belonging. Awareness of this relationship has both immediate implications for students' sense of belonging at their respective institutions and 
12 International Journal of Research on Service-Learning and Community Engagement

future implications for educational achievement and attainment. Thus, service-learning courses may offer a promising way forward for beginning to address the persistent educational attainment gap for students from lower income backgrounds.

\section{References}

Astin, A. W. (1993). What matters in college: Four critical years revisited. San Francisco, CA: Jossey-Bass.

Astin, A. W., \& Sax, L. J. (1998). How undergraduates are affected by service participation. Journal of College Student Development, 39(3), 251-263.

Astin, A. W., Vogelgesang, L. J., Ikeda, E. K., \& Yee, J. A. (2000). How service learning affects students. Los Angeles, CA: UCLA, Higher Education Research Institute.

Austin, P. C. (2011). An introduction to propensity score methods for reducing the effects of confounding in observational studies. Multivariate Behavioral Research, 46(2), 399-424.

Basto, M., \& Pereira, J. M. (2012). An SPSS R-Menu for ordinal factor analysis. Journal of Statistical Software, 46(4), 1-29.

Baumeister, R. F., \& Leary, M. R. (1995). The need to belong: Desire for interpersonal attachments as a fundamental human motivation. Psychological Bulletin, 117, 497-529.

Bourdieu, P., \& Passeron, J. C. (1977). Reproduction in education, culture, and society. London, UK: Sage.

Brownell, J. E., \& Swaner, L. E. (2009). High-impact practices: Applying the learning outcomes literature to development of successful campus programs. Peer Review, 11(2), 26-30.

Carnevale, A. P., Smith, N., \& Strohl, J. (2013). Recovery: Projection of jobs and education requirements through 2020. Washington, DC: Georgetown University Center on Education and the Workforce.

Carver, R. L. (1997). Theoretical underpinnings of service learning. Theory into Practice, 36(3), $143-149$.

Chatman, S. (2011). SERU project technical report: No evidence of substantive nonresponse bias for the 2011 administration. Berkeley, CA: UC Berkeley, Center for Studies in Higher Education.

Costello, A. B., \& Osborne, J. W. (2005). Best practices in exploratory factor analysis: Four recommendations for getting the most from your analysis. Practical Assessment, Research, and Evaluation, 10(7), 1-9.

Courtney, M. G. R. (2013). Determining the number of factors to retain in EFA: Using the SPSS Rmenu v2.0 to make more judicious estimates. Practical Assessment, Research, \& Evaluation, $18(8), 1-14$.

Cruce, T. M., \& Moore, J. V. (2007). First-year students' plans to volunteer: An examination of the predictors of community service. Journal of College Student Development, 48(6), 655-673.

Dennis, J. M., Phinney, J. S., \& Chuateco, L. I. (2005). The role of motivation, parental support, and peer support in the academic success of ethnic minority first-generation college students. Journal of College Student Development, 46(3), 223-236.

Douglass, J. A., Thomson, G., \& Zhao, C. (2012). The learning outcomes race: The value of selfreported gains in large research universities. Higher Education, 64, 317-335.

Eyler, J. (2002). Reflection: Linking service and learning - linking students and communities. Journal of Social Issues, 58(3), 517-534. doi:10.1111/1540-4560.00274

Eyler, J. S., \& Giles, D. E., Jr. (1999). Where's the learning in service-learning? San Francisco, CA: Jossey-Bass.

Fink, J. E. (2014). Flourishing: Exploring predictors of mental health within the college environment. Journal of American College Health, 62(6), 380-388. 
Furco, A., Jones-White, D., Huesman, R., Jr., \& Gorny, L. S. (2016). Modeling the influence of service-learning on academic and sociocultural gains: Findings from a multi-institutional study. In K. M. Soria \& T. D. Mitchell (Eds.), Civic engagement and community service at research universities: Engaging undergraduates for social justice, social change, and responsible citizenship (pp. 143-163). London, UK: Palgrave Macmillan.

Gelman, A., \& Hill, J. (2007). Data analysis using regression and multilevel/hierarchical models. New York, NY: Cambridge University Press.

Hale, C. J., Hannum, J. W., \& Espelage, D. L. (2005). Social support and physical health: The importance of belonging. Journal of American College Health, 53, 276-284.

Han, C-W., Farruggia, S. P., \& Moss, T. P. (2017). Effects of academic mindsets on college students' achievement and retention. Journal of College Student Development, 58(8), 1119 1134.

Hansen, B. B., \& Bowers, J. (2008). Covariate balance in simple, stratified, and clustered comparative studies. Statistical Science, 23(2), 219-236.

Hatcher, J. A., \& Bringle, R. G. (1997). Reflection: Bridging the gap between service and learning, College Teaching, 45(4), 153-158. doi:10.1080/87567559709596221

Hausmann, L. R. M., Schofield, J. W., \& Woods, R. L. (2007). Sense of belonging as a predictor of intentions to persist among African American and White first-year college students. Research in Higher Education, 48, 803-839.

Hedges, L. V., \& Hedberg, E. C. (2007). Intraclass correlation values for planning group-randomized trials in education. Educational Evaluation and Policy Analysis, 29, 60-87.

Hurst, A. L. (2010). The burden of academic success: Managing working-class identities while in college. New York, NY: Rowman \& Littlefield.

Hurst, A. L. (2012). College and the working class: What it takes to make it. Rotterdam, The Netherlands: Sense.

Hurtado, S., \& Carter, D. F. (1997). Effects of college transition and perceptions of the campus racial climate on Latino college students' sense of belonging. Sociology of Education, 70, 324-345.

Hurtado, S., \& Guillermo-Wann, C. (2013). Diverse learning environments: Assessing and creating conditions for student success-Final report to the Ford Foundation. Los Angeles, CA: UCLA, Higher Education Research Institute.

Iacus, S. M., King, G., \& Porro, G. (2009). CEM: Coarsened exact matching software. Journal of Statistical Software, 30, 1-27.

Iverson, S. V., \& James, J. H. (2013). Self-authoring a civic identity: A qualitative analysis of change-oriented service learning. Journal of Student Affairs Research and Practice, 50(1), $88-105$.

Johnson, D. R., Soldner, M., Leonard, J. B., Alvarez, P., Inkelas, K. K., Rowan-Kenyon, H. T., \& Longerbeam, S. D. (2007). Examining sense of belonging among first-year undergraduates from different racial/ethnic groups. Journal of College Student Development, 48(5), 525542.

Johnson, M., Dugan, J. P., \& Soria, K. M. (2017). Try to see it my way: What influences social perspective taking among college students? Journal of College Student Development, 58(7), $1035-1054$.

King, G., \& Nielsen, R. (2016). Why propensity scores should not be used for matching. Political Analysis, 27(4). Retrieved from http://j.mp/2ovYGsW

Kuh, G. D. (2003). What we're learning about student engagement from NSSE: Benchmarks for effective educational practices. Change: The Magazine of Higher Learning, 35, 24-32.

Lester, J., Brown Leonard, J., \& Mathias, D. (2013). Transfer student engagement: Blurring of social and academic engagement. Community College Review, 41, 202-222.

Maestas, R., Vaquera, G. S., \& Muñoz Zehr, L. (2007). Factors impacting sense of belonging at a Hispanic-serving institution. Journal of Hispanic Higher Education, 6, 237-256. 
14 | International Journal of Research on Service-Learning and Community Engagement

Marks, H. M., \& Jones, S. R. (2004). Community service in the transition: Shifts and continuities in participation from high school to college. Journal of Higher Education, 75, 307-339.

Mitchell, T. D., Schneider, F. J., \& Soria, K. M. (2017). Queer and trans* in community engagement: Understanding LGBTQ participation in service. Houston, TX: Association for the Study of Higher Education.

Museus, S. D., Yi, V., \& Saelua, N. (2017). The impact of culturally engaging campus environments on sense of belonging. Review of Higher Education, 40(2), 187-215.

National Center for Education Statistics. (2015). Postsecondary attainment: Differences by socioeconomic status. Washington, DC: U.S. Department of Education. Retrieved from https://nces.ed.gov/programs/coe/pdf/coe tva.pdf

National Center for Education Statistics. (2017). Percentage of recent high school completers enrolled in college, by income level: 1975 through 2016. Washington, DC: U.S. Department of Education. Retrieved from https://nces.ed.gov/programs/digest/d17/tables /dt17_302.30.asp

Nora, A., Kramer, B., \& Itzen, R. (1996, November). Persistence among non-traditional Hispanic college students: A causal model. Paper presented at the annual meeting of the Association for the Study of Higher Education, Albuquerque, NM.

Nuñez, A. (2009). A critical paradox? Predictors of Latino students' sense of belonging in college. Journal of Diversity in Higher Education, 2, 46-61.

Ostrove, J. M., \& Long, S. M. (2007). Social class and belonging: Implications for college adjustment. Review of Higher Education, 30(4), 363-389.

Pak, C-S. (2018). Liking service-learning with sense of belonging: A culturally relevant pedagogy for heritage students of Spanish. Journal of Hispanic Higher Education, 17(1), 76-95.

Paulsen, M. B., \& St. John, E. P. (2002). Social class and college costs: Examining the financial nexus between college choice and persistence. Journal of Higher Education, 73(2), 189-236.

Peikes, D. N., Moreno, L., \& Orzol, S. M. (2008). Propensity score matching. American Statistician, 62(3), 222-231.

Raiche, G., Roipel, M., \& Blais, J. G. (2006). Non-graphical solutions for the Cattell's scree test. Paper presented at the international annual meeting of the Psychometric Society, Montreal.

Reason, R. D. (2009). An examination of persistence research through the lens of a comprehensive conceptual framework. Journal of College Student Development, 50(6), 659-682.

Rosenbaum, P. R., \& Rubin, D. B. (1985). Constructing a control group using multivariate matched sampling methods that incorporate the propensity score. American Statistician, 39(1), 33-38.

Rubin, D. B. (1973). The use of matched sampling and regression adjustment to remove bias in observational studies. Biometrics, 29, 185-203.

Rubin, M. (2011). Social class differences in social integration among students in higher education: A meta-analysis and recommendations for future research. Journal of Diversity in Higher Education, 5(1), 22-38.

Serow R., \& Dreyden, J. (1990). Community service among college and university students: Individual and institutional relationships. Adolescence, 25, 553-566.

Singell, L. D., Jr. (2004). Come and stay a while: Does financial aid affect retention conditioned on enrollment at a large public university? Economics of Education Review, 23(5), 459-471.

Soria, K. M. (2015a). Reading, learning, and growing: An examination of the benefits of common book reading programs for college students' development. Journal of the First-Year Experience and Students in Transition, 27(1), 29-47.

Soria, K. M. (2015b). Welcoming blue collar scholars into the ivory tower: Developing classconscious strategies for students' success. Columbia, SC: National Resource Center for the First-Year Experience and Students in Transition.

Soria, K. M., \& Alkire, D. B. (2015). Elevating Native American college students' sense of belonging in higher education. Developments, 13(3). Retrieved from 
https://www.myacpa.org/article/elevating-native-american-college-students-sensebelonging-higher-education

Soria, K. M., \& Barratt, W. (2012). Examining class in the classroom: Social class data in institutional/academic research. New Orleans, LA: Association for Institutional Research.

Soria, K. M., \& Bultmann, M. (2014). Advising scholars from blue collar backgrounds: Supporting working-class students' success in higher education. NACADA Journal, 34(2), 51-62.

Soria, K. M., \& Mitchell, T. D. (2015). Learning communities: Foundations for first-year students' development of pluralistic outcomes. Learning Communities Research and Practice, 3(2), 121.

Soria, K. M., \& Stebleton, M. J. (2013). Major decisions: Implications for satisfaction and sense of belonging. NACADA Journal, 33(2), 1-15.

Soria, K. M., Stebleton, M. J., \& Huesman, R. L. (2013-2014). Class counts: Exploring differences in academic and social integration between working-class and middle/upper-class students at large, public research universities. Journal of College Student Retention: Research, Theory, and Practice, 15(2), 215-242.

Soria, K. M., \& Thomas-Card, T. (2014). Relationships between motivations for community service participation and desire to continue service following college. Michigan Journal of Community Service Learning, 20, 53-64.

Soria, K. M., Troisi, J. N., \& Stebleton, M. J. (2012). Reaching out, connecting within: Community service and sense of belonging among college students. Higher Education in Review, 9, 6585.

Stebleton, M. J., Soria, K. M., \& Huesman, R. L. (2014). Recent immigrant students at research universities: The relationship between campus climate and sense of belonging. Journal of College Student Development, 55(2), 196-202.

Strayhorn, T. L. (2012). College students' sense of belonging: A key to educational success for all students. New York, NY: Routledge.

Stuart, E. (2010). Matching methods for causal inference: A review and a look forward. Statistical Science, 25(1), 1-21.

Thoemmes, F. J. (2012). Propensity score matching in SPSS. Retrieved from http://arxiv.org/ftp/arxiv/papers/1201/1201.6385.pdf

Velásquez, P. (1999, November). The relationship between cultural development, sense of belonging, and persistence among Chicanos in higher education: An exploratory study.

Paper presented at the annual meeting of the Association for the Study of Higher Education, San Antonio, TX.

Velicer, W. F. (1976). Determining the number of components from the matrix of partial correlations. Psychometrika, 41, 321-327.

Velicer, W. F., Eaton, C. A., \& Fava, J. L. (2000). Construct explication through factor or component analysis: A review and evaluation of alternative procedures for determining the number of factors or components. In R. D. Goffin \& E. Helmes (Eds), Problems and solutions in human assessment: Honoring Douglas N. Jackson at seventy (pp. 41-71). Boston, MA: Kluwer.

Walton, G. M., \& Cohen, G. L. (2011). A brief social-belonging intervention improves academic and health outcomes of minority students. Science, 331(6023), 1447-1451.

Weiler, L., Haddock, S., Zimmerman, T. S., Krafchick, J., Henry, K., \& Rudisill, S. (2013). Benefits derived by college students from mentoring at-risk youth in a service-learning course. American Journal of Community Psychology, 52(3-4), 236-248.

Wessel, R. D., Bell, C. L., McPherson, J. D., Costello, M. T., \& Jones, J. A. (2006). Academic disqualification and persistence to graduation by financial aid category and academic ability. Journal of College Student Retention, 8(2), 185-198.

Wilson, J. C. (2011). Service learning and the development of empathy in U.S. college students. Education + Training, 53(2/3), 207-217. 
16 | International Journal of Research on Service-Learning and Community Engagement

Yeh, T. L. (2010). Service-learning and persistence of low-income, first-generation college students: An exploratory study. Michigan Journal of Community Service Learning, 16(2), 50-65.

York, T. T. (2016). Exploring service-learning outcomes and experiences for low-income, firstgeneration college students: A mixed-methods approach. International Journal of Research on Service-Learning and Community Engagement, 4(1), 309-342.

York, T. T., \& Fernandez, F. (2018). The positive effects of service-learning on transfer students' sense of belonging: A multi-institutional analysis. Journal of College Student Development, 59(5), 579-597.

\begin{abstract}
About the Authors
Krista M. Soria is an analyst in the Office of Institutional Research at the University of Minnesota Twin Cities.

Ashley S. Hufnagle is a graduate research assistant in the Department of Educational Psychology at the University of Minnesota - Twin Cities.

Isabel Lopez-Hurtado is a graduate student in the Department of Educational Psychology at the University of Minnesota - Twin Cities.

Tai Do is a graduate student in the Department of Educational Psychology at the University of Minnesota - Twin Cities.

Correspondence concerning this article should be addressed to Krista M. Soria at ksoria@umn.edu.
\end{abstract}

